\title{
Home-made development in Bolivia
}

\author{
Desenvolvimento autóctone na Bolívia
}

\author{
Sue A. S. Iamamoto*
}

\begin{abstract}
This article investigates how the neighbourhood movement of the city of El Alto, a key social movement in contemporary Bolivia, depicted and constructed ideas of development during the protests of October 2003, the so-called "Gas War". Their perspective was both informed by transnational ideologies — such as progress, modernisation and development - and the deeply rooted collective memory of the War of the Pacific. Differently from other nationalist experiences, this "looking back to move forwards" movement sought to re-stablish a balance of powers, instead of promoting group superiority. This emphasis on equality brings possibilities of dialogue with the emerging development paradigm of vivir bien (living well). This paper, thus, contributes to a more general discussion on the conflict between developmentalism and vivir bien in Latin America. Instead of quickly dismissing this new paradigm as being too normative and distant from the realities of poor people, it identifies the potential encounters between them.
\end{abstract}

Keywords: Development. Living well. Neoextrativism. Bolivia. El Alto.

Resumo: Este artigo investiga como o movimento de bairro da cidade de El Alto, um movimento social chave na Bolívia contemporânea, retratou e construiu ideias de desenvolvimento durante os protestos de outubro de 2003, a chamada "Guerra do Gas". Sua perspectiva era informada por ideologias transnacionais - como o progresso, a modernização e o desenvolvimento - e a memória coletiva profundamente enraizada da Guerra do Pacífico. Diferentemente de outras experiências nacionalistas, esse movimento que "avança enquanto olha para trás" procurou reestabelecer um equilíbrio de poderes em vez de promover a superioridade do grupo. Essa ênfase na igualdade traz possibilidades de diálogo com o paradigma de desenvolvimento emergente de vivir bien. Este artigo contribui para uma discussão mais geral sobre o conflito entre o desenvolvimento e o vivir bien na América Latina. Em vez de descartar rapidamente este novo paradigma como sendo demasiado normativo e distante das realidades das pessoas pobres, identifica os possíveis encontros entre eles.

Palavras-chave: Desenvolvimento. Vivir bien. (Neo)extrativismo. Bolívia. El Alto.

* PhD in Political Science at the Mary University of London (Great Britain), lecturer in Political Scienceat theUniversidadeFederaldaBahia(Ufba)inSalvador,BA, Brazil<sueiamamoto@yahoo. com>. Previous versions of this paper's arguments appeared in Iamamoto (2015) and in a paper presented during the conference "The Andean region today: political, international and economic challenges" organised by the Latin American Centre of the University of Oxford, 5-6 May 2016. I am grateful for the comments received at this particular event and from the anonymous reviewers of this journal. I am also grateful for Jay Lingham and Andrew Scyner's careful proofreading. The research data was collected during a doctoral investigation carried out at Queen Mary University of London, under the supervision of James Dunkerley and funded by Capes (Brazil).

Civitas, Porto Alegre, v. 17, n. 2, p. 233-250, maio-ago. 2017

Exceto onde especificado diferentemente, a matéria publicada neste periódico

é licenciada sob forma de uma licença

Creative Commons Attribution-NonCommercial-NoDerivatives 4.0 International License 
Developmentalism has been one of the key characteristics of Latin American progressive governments over the last two decades, be they governments more critical of US imperialism and mainstream economic policies, such as Venezuela and Bolivia, or with more ambiguous standpoints, such as Brazil and Chile. In a region where neoliberal policies blossomed during the last decades of the twentieth century, causing unwelcome state shrinkage, the new take on local industrialisation, the building of impactful infrastructure and the support for native enterprises and bourgeoisies had very strong popular appeal.

As expected, criticism from right-wing commentators appeared, arguing that the problems of development would be better served with (neo)liberal policies instead of state interventionism (Easterly, 2009). But the novelty was actually the criticism coming from left-wing actors, who pointed out that this new state developmentalism undermined the most innovative face of the Latin American pink tide: the radical political inclusion of previously excluded groups, such as indigenous peoples, which meant a more democratic and plural way of governing, a reformulation of the state as diverse and multicultural, and compromise in order to establish a more sustainable relationship with the environment.

Bolivia, with her new political constitution approved by popular referendum in 2009, was seen as one of the countries that was the most advanced in this particular direction, becoming a plurinational state and recognising many collective rights of indigenous peoples. However, Evo Morales' government was not isolated from the developmentalist tide, investing in the construction of highways and other infrastructure projects and maintaining the country's dependence on natural resources extractivism. This new form of extractivism, only different from the neoliberal model because it was used to fund social policies, caused, equally, the dispossession of natural resources, traditional territories and collective rights (Svampa, 2015; Svampa; Viale, 2014).

As soon as these two different paradigms of development, which I call in this article developmentalism and vivir bien (living well), crystallised in the public debate, attention was shifted towards how representative they were of the Bolivian population, particularly of the diverse social movements that constituted Evo Morales' base of support. While the government was accused of authoritarianism and of betraying the expectations of indigenous peoples, organisations that criticised the government were labelled pro-imperialists and unrepresentative of the general expectations of the Bolivian people. ${ }^{1}$

\footnotetext{
${ }^{1}$ For a quick review of this conflict, see Svampa (2015).
} 
To shed new light on the debate, this article investigates how an important social movement in Bolivia, the neighbourhood movement of the city of El Alto, has depicted and constructed its ideas of development. This is relevant because these ideas are a result of both objective situations - the needs and problems emerging from daily lives - and subjective constructions, which are related to transnational movements of ideas and to local histories and identities. When the constructed character of these perspectives is recognised and when the social analysis and the normative aspects of these development paradigms are separated, new characterisations and possibilities appear.

To illustrate my argument, I first present how developmentalism appeared during a key cycle of protest in October 2003 in the city of El Alto, before the ascension of Morales to the presidency, during the so-called "Gas War". Secondly, I analyse the appearance, during the protests, of the collective memory of the War of the Pacific and how it expressed a very popular idea of "stolen development". The role of collective memories and stable versions of the past are then discussed to understand how transnational ideologies - such as progress, modernisation and development - can find their roots in local societies. Differently from other nationalist experiences, this "looking back to move forwards" movement seeks to re-establish a balance of powers, instead of promoting group superiority. Finally, the emergence of the vivir bien paradigm in the Bolivian political arena will be detailed, accessed, as it was, according to its potential to resonate not only among traditional indigenous groups but also among urban actors such as the alteños.

This article draws on empirical data collected between 2012 and 2013 in the city of El Alto, which comprised 20 unstructured interviews with rank-andfile participants and social leaders, as well as data collection from secondary sources and media reports (newspapers and radio programmes).

\section{The developmentalism of October 2003}

El Alto is a city adjacent to La Paz (Bolivia's government seat), home to around 800,000 people, many of whom have strong economic and family ties to the highland rural countryside of La Paz department. Thus, when the government of Sánchez de Lozada violently repressed a peasant blockade in September 2003 in an episode known as the Warisata massacre, killing six people, the alteños (inhabitants of El Alto) started to call for the president's resignation. At the same time as the conflict in the countryside was escalating, the government was planning to sign a natural gas export deal with transnational companies, which established very low prices for the resource and favoured 
Chilean cities as the main ports of export. ${ }^{2}$ When details of the plan came to light, they invoked the ire of Bolivian social movements and nationalist sectors of society. By the beginning of October, the general assembly of the Federation of Neighbourhood Councils (Fejuve) of El Alto had decided to start an open-ended civic strike, demanding the president's resignation and the non-exportation, nationalisation and industrialisation of natural gas, a petition that was later baptised the "October agenda". Sánchez de Lozada, once again, reacted with violence against the activists, killing almost 60 people in operations to unblock the main roads of the city, whose barricades were causing fuel and food shortages in the city of La Paz. After such bloodshed, the political support of Sánchez de Lozada crumbled and he resigned on 17 October 2003.

The so-called Gas War marked an important turning point in national politics. It highlighted a left-wing nationalist demand to have local resources used to benefit Bolivians, particularly through their industrialisation: "There was a clamour saying the gas is going neither through Chile nor Peru; gas for Bolivians first. Nationalisation, industrialisation. This was a fundamental clamour", explained Carlos Rojas, a member of the mobilisation committee of District Four during October 2003 (interview on 13 June 2013).

As inheritors of a Latin American nationalist left, alteños identified the lack of industrialisation and the export of products without added value as key problems facing Bolivia. As long as it was to industrialise the country, extractivism was seen as a solution:

We were analysing [those issues] in the political commission [of Fejuve], and we believed that gas could generate big transformations in the country, it could create a lot of jobs, it could contribute to gross domestic product. It could generate a series of added values, if it was industrialised in the country, if it was not only sold as raw material. So, we had this analysis that this was a strategic product in Bolivia, and, therefore, the struggle was concentrated around hydrocarbons (Vicente Fernández, interview on 23 May 2013).

The expectations raised by the nationalisation of gas were also fed by a comparison with neighbouring countries. With a developmentalist government, Bolivia would then be able to catch up with other countries in the region, particularly regarding the offering of basic social services:

\footnotetext{
${ }^{2}$ According to Gomez $(2004$, p. 41 ), this price corresponded to only $20 \%$ of the standard gas price in international markets.
} 
[We wanted] the state to apply some policies that would help the population to move forward, as they do in neighbouring countries, such as Peru, Chile, Brazil. [...] We had all the resources, we had analysed [...], but there was no capacity to properly manage the state. [...] We asked the government to establish industries in Bolivia, to improve living conditions, that there be more professionals, and that they have work in their own country, that they would not need to migrate from country to country (Felipa Catacora, interview on 25 March 2013).

While expressing their views on their expectations through the mobilisation in 2003, alteños articulated a perspective of development that was in line with dependency theorists, who emphasised the structural role of the capitalist world system in creating underdevelopment in the periphery by keeping "third-world" countries as non-industrialised providers of natural resources. The activists also, on a smaller scale, echoed more traditional Western modernisation theories, which emphasised the endogenous conditions of underdevelopment, such as mismanagement by political elites, and envisaged the possibility of poor countries "catching up" despite the world's structural economic conditions. ${ }^{3}$ In any case, this developmentalism, mainly inherited from left-wing groups in Bolivia, ${ }^{4}$ stressed the importance of industrialisation and did not oppose extractivism as a principle, since it could represent a solution for an under-funded state to promote industrialisation and social policies.

However, there was another idiom through which the expectations around Bolivia's development were expressed. During the protest days in October 2003, the struggle to nationalise gas appealed to a very significant national symbol: the maritime demand.

\section{The echoes of the seacoast}

When analysing how activists justified their motivation to participate in the 2003 struggles, the collective memory of the War of the Pacific (1879) appeared many times. ${ }^{5}$ This war, a symbol of the long-standing "wound" of the loss of half of the national territory during the nineteenth and early twentieth century, was described by some commentators as one of the most important features of Bolivian nationalism. ${ }^{6}$ The war was fought initially over Bolivia's

\footnotetext{
${ }^{3}$ For a very useful review of such perspectives on development, see Carballo (2014).

${ }^{4}$ Many leaders of Fejuve in 2003 emphasised the importance of the workshops and seminars on the gas theme that were carried out with left-wing intellectuals and experts, such as Álvaro García Linera, current vice president of Bolivia.

${ }^{5}$ Of the 20 activists interviewed in El Alto, 12 cited the War of the Pacific.

${ }^{6}$ See Demelas (1980, p. 28), Ortega (1973, p. 1) and Perrier Bruslé (2013, p. 49).
} 
seacoast provinces, which were rich in guano and nitrate. After a dispute over the taxes charged by the Bolivian government on nitrate exports, the Chilean army invaded the region and Bolivia never managed to take it back. ${ }^{7}$ The conflict cost Bolivia 120,000 square kilometres of territory and 400 kilometres of coast line (Presidency of the Republic Bolivia, 2004).

Since the war, Bolivians have never ceased to publically remember the lost seacoast. In schools, children are taught to sing anthems for the lost territory and to become familiar with the original shape of the Bolivian map. The topic of "besieged sovereignty" is a very common one in classrooms (Luykx, 1999, p. 136) and there is a national commemoration day, the Day of the Sea (23 March), that regularly brings the Bolivian maritime claim to the fore.

Alteños in 2003, therefore, were quite representative of the rest of Bolivian society with regards to the memory of the War of the Pacific. The war was remembered when people started to complain about the export of the gas through a port in Chile, which was seen as a neighbouring country that has developed itself at the expense of Bolivian resources. This perception can be seen in the testimony given by Isabel Álvarez, a young activist of the street traders' movement during the 2003 struggles:

They said they wanted to sell the gas to another country, to Chile. But we didn't want that, because the Chileans have taken the sea, Antofagasta, from us with a war. [...] Because of that we started to struggle; how is it possible that Goni [Gonzalo Sánchez de Lozada] wants to sell something that is ours to the Chileans? This is how it has started. Otherwise, there would be no Gas War (Interview on 6 December 2012).

People also perceived the gas and the seacoast as resources that needed to be recovered and this feeling was attached to an idea of Bolivian nationhood. During October 2003, one could hear people singing the following lines: "The population is present, Bolivia, El Alto, demands the gas. Recover, recover, recover, recover!", making clear reference to a very popular military march called "Let's recover our sea". 8 Thus, the War of the Pacific served to depict a feeling of a "stolen development" related to lost resources, be they the sea or the gas.

\footnotetext{
${ }^{7}$ Peru entered the war to support Bolivia because of a military cooperation pact. Bolivia abandoned the war in 1880 but Chile furthered its military offensive until 1884, occupying the southern provinces of Peru, which were also rich in nitrate and guano, and reaching Lima.

${ }^{8}$ See Radio Pachamama (2004), Track 3, 3'20'.
} 
The memory of the lost seacoast played the role of supporting the mobilisation, providing the activists with a known narrative that assisted them in making sense of new and challenging situations. On one hand, this recalling was instrumental: it was a popular narrative used by the activists - sometimes in a conscious way, sometimes in a more automatic way - to foster mobilisation. Maurice Halbwachs once famously claimed that collective memories are mainly determined by the contemporary needs of groups living in the present. In a hypothetical competition between the constraints of the past and of the present, the only "framework that counts" is the one "constituted by the commandments of our present society and which necessarily excludes all the others" (Halbwachs, 1992, p.50). Other authors have emphasised the narrative role of these memories in interpreting new events, working as "prisms" (Huyssen, 2003, p. 98) or "platforms" (Rothberg, 2009, p. 3) that replicate metaphors, symbols and political judgements from past situations in the present.

At the same time, combined with social movement theories, collective memories work in the mobilisation process as interpretative frames (Benford; Snow, 2000) and stories (Selbin, 2008), which provide the actors with a message of injustice (Gamson, 1992) that can be used to interpret the present and foster collective action. However, calling these narratives "collective memories" emphasises their elements that are not strategically related to the mobilisation itself, their constitutive character, which is precisely what allows them to be so powerful and instrumental. As the memory of the War of the Pacific demonstrates, collective memories are embedded in people's everyday lives and the most basic processes of socialisation, such as schooling and public celebrations, and are related to our understandings of space, such as the imagination of the national territory as something dismembered.

\section{Looking back to move forwards}

Activists from ElAlto presented two distinct features in their interpretation of 2003. Although they perceived a past event related to their national or regional history as an inspiration for their struggle, their projection of the future was marked by a left-wing developmentalism and anti-imperialism, which corresponded to a more transnational ideological movement than a specific national political project based on past traditions. In other words, the recovering of the past did not entail — at least among the movements studieda nostalgia for past times.

During the process of struggle studied here, the memory of the seacoast did not contradict the political project being defended, but assisted it in 
becoming more widespread and popular. Actually, one could reasonably argue that it was the strength of this memory that provided local appeal to a more universal left-wing project of developmentalism. Historically in Latin America, left-wing parties and movements, inspired by a more internationalist perspective on social change and equality, struggled to root their demands among the popular sectors whose interests they were supposed to be defending. What can be noticed with the appearance of collective memories during the struggles is that, by looking back at their remarkable national past events, Bolivian social movements were able to find more rooted motivations to struggle for these ideas shared with the outside world. Through the frame of "stolen" development, of a need to recover resources from grasping international agents, through a metaphorical equivalence between sea and gas, the activists' demands for nationalisation and industrialisation popularised quickly in October 2003. As we have seen, the projection of this future development is very close to an international paradigm of modernisation, but the justification for it comes with a popular narrative of a particular historical experience.

It is tempting to equate this "looking back to move forwards" movement with theories of nationalism, especially the work of Tom Nairn. In his view, nationalism would be a result of the unequal development of capitalism, "the machineries of the world political economy" (Nairn, 2003, p. 323). The elites of peripheral countries, realising that the modernisation enjoyed by the core capitalist countries was not developing naturally in the periphery, and actually was translating into imperialism and exploitation, started to resort to their own mythical and heroic past to gain strength to undertake their own shortcuts to development (Nairn, 2003, p. 336).

While recognising the importance of this phenomenon in "third world" struggles for national liberation, against colonialism and imperialism, Nairn also emphasises the dangerous and irrational features it carries. "Again, this is emphatically not to say that all forms of nationalism are as good, or as bad, as one another [...]. The whole family is spotted, without exception. Forms of 'irrationality' (prejudice, sentimentality, collective egotism, aggression, etc.) stain the lot of them" (Nairn, 2003, p. 336). However, the understanding of this looking towards the past as an irrational impulse, a necessarily "regressive force", is problematic and insufficient to understand the Bolivian case. As

\footnotetext{
${ }^{9}$ Studying processes of struggle in Bolivia, Hylton and Thomson (2007, p. 149) have identified that indigenous people articulate a perception of time that takes lessons from the past to deal with the open future, as evidenced by the Aymara expression "to walk ahead while looking back" (qhip nayr uñtasis sartañani).
} 
discussed earlier, a collective memory appears as both instrumental for and constitutive of the actors. It is a "platform" to understand new social situations and realities.

Differently from Nairn's "idealistic and romantic wellsprings", which seem to indicate some sort of golden age, the collective memory studied here actually recovers a past of suffering and unfairness. Instead of a perception of an injustice that should be overcome through a complete reversal of power and the affirmation of a national superiority, the memory of the War of the Pacific depicts an idea of imbalance. It expresses an injustice that was committed in the past and requires reparations in the present so that a balanced situation can be achieved again. The war symbolised the suffering of Bolivians vis-à-vis voracious international aggressors, who condemned the country to underdevelopment. In El Alto, hydrocarbons were seen as resources that needed to be recovered from imperialist powers, as was the seacoast, while national political adversaries were discredited as being vende-patrias (traitors to the fatherland) or Chileans. The recovering of these resources was a condition for Bolivia to start building its path towards development, achieving a situation of balance.

It is curious to notice that, despite all the emotion involved in denouncing Chilean interests in Bolivia, people stated that they had nothing against Chile as such: "It was not a Fejuve's policy to be against a country, the fundamental was to recover the natural resources that were being given to other companies, to benefit other countries, rather than our country Bolivia", said Vicente Fernández (Interview on 23 May 2013). Alteños were actually against the idea that one side would benefit at the expense of the other, frequently using the expression of "outstanding debts" (cuentas pendientes).

To sum up, it is possible to identify an impulse towards development and progress in the political expectations of activists in El Alto. But this impulse does not come in its traditional package of group superiority, and the main demand is the (re)establishment of a balanced situation between the opposing sides. This brings us to the final section's discussion: how these expectations of development and patterns of evaluation of political life are related to the idea of vivir bien, a paradigm that emerged in the political arena after the election of Evo Morales.

\section{Developmentalism versus Vivir Bien}

October 2003 was one in a series of protest events that have shaken Bolivian politics, destabilising traditional political parties, leaderships and 
institutions. ${ }^{10}$ After the resignation of Sánchez de Lozada, Carlos Mesa, his vice president, took charge of the government until 2005, when he resigned during a crisis caused, among other things, by his hesitation in dealing with the nationalisation of natural gas. After a succession crisis, new elections were called and Evo Morales, a leader of the coca growers' movement and leftwing politician, was elected with $53.7 \%$ of the valid votes. In his inauguration speech in 2006, Morales famously claimed he would "rule obeying the people" (Morales, 2006), strongly compromising his government with the agenda of social movements (Postero, 2010).

Although the October agenda played an important role in defining the government's first steps, such as the nationalisation of hydrocarbons, ${ }^{11}$ the expectations of Bolivian social movements were not restricted to this particular aspect of national development. They advocated for the reformulation of the country's political and legal system through a constitutive assembly, which would "re-found" the Bolivian state's relationship with society. Indigenous groups in particular advocated for a representation system that would include their political practices, and a state form that would recognise their territorial and cultural rights.

In response to these expectations, the New State Constitution approved in 2009 inaugurated a plurinational state acknowledging the existence of preColumbian nations and peoples, officialised 36 indigenous languages, turned the wiphala (a flag with a chequered rainbow that represented the Qullasuyo jurisdiction of the old Inca state) a national symbol, and argued that the national economic and political systems should be guided by the principle of pluralism (Iamamoto, 2013, p. 224-230). ${ }^{12}$ These achievements were the result of an intense participation of peasant and indigenous movements in the Constitutional Assembly, either through the MAS (Movimiento al Socialismo) - the governing party - or other civic organisations. This participation was only possible because of a coalition called Pact of Unity, a forum that proposed a common language of state re-foundation to the assembly (Pannain, 2014).

\footnotetext{
${ }^{10}$ For a review of this period, which started in 2000 with the Water War in Cochabamba, see Gutierrez (2008), Iamamoto (2013), Hylton and Thomson (2005; 2007), Pannain (2014, p. 99-150), Perreault (2006) and Webber (2011a).

${ }^{11}$ The nationalisation of hydrocarbons in Bolivia is a contested topic. Even though the government managed to increase its revenue substantially through new contracts with multinationals, it was unable to revitalise the production capabilities of the state hydrocarbons company (YPFB) and to industrialise the resource, as envisaged by activists in October 2003. For a detailed analysis of the nationalisation, see Webber (2011b, p. 80-83)

${ }^{12} \mathrm{On}$ the Bolivian constitutional process and resulting constitution, see Gamboa Rocabado (2009), Iamamoto (2013, 2016), Leonel Junior (2015) and Schavelzon (2012). On the horizons of plurationality and its contested nature within Bolivian politics and society, see Cunha Filho (2015) and Freitas (2013).
} 
Analysts of popular engagement in the constitutional process emphasised how the movements' demands went beyond liberal multiculturalism by proposing an equal hierarchy between individual and collective rights (Garcés, 2011, p. 54).

These popular measures faced strong regionalist and right-wing opposition in the Eastern departments, and the government relied heavily on peasant, indigenous and urban social movements to support its legitimacy. After this initial period of "catastrophic equilibrium" (empate catastrófico) (García Linera, 2008) that mobilised the energies of Morales' first term (2006-2010) almost entirely, the left-wing administration managed to gather a governing majority. From the second term on, marked by the MAS hegemony over the country's main political institutions, the former "creative" tensions inside the government and its supporting social movements started to crystallise.

On one hand, there was a growing governmental effort to promote the idea of vivir bien (good living) as an alternative development paradigm, particularly through the Ministry of Foreign Affairs headed by David Choquehuanca. The paradigm unified environmental concerns with the defence of indigenous rights and cosmovisions, proposing the idea of "good living" as opposed to an individualistic and capitalist perspective of human development. ${ }^{13}$ On the other hand, the majority of the government's internal policies were inspired by traditional left-wing developmentalism. As seen before, this perspective articulated a strong emphasis on industrialisation, state interventionism, huge infrastructure projects and the promotion of local capitalism, ${ }^{14}$ and relied heavily on extractivism as a main economic driving force.

The tension between the two paradigms gained visibility during the dispute over the construction of a highway that crossed the Isiboro Sécure Indigenous Territory and National Park (Tipnis). Despite local indigenous opposition, the government insisted on carrying out the project, claiming it would connect different regions of the country and develop local economies. Indigenous people living in the territory, though, criticised the plan precisely because of the idea of "development" it entailed: to disrupt the region with a highway that would bring not only outsiders but also the possibility of exploring the region's natural resources, deeply affecting local traditions and customs (McNeish, 2013; Moraes, 2014). These and other similar conflicts have led

\footnotetext{
${ }^{13}$ The Ministry of Foreign Affairs edited an illustrative volume on the many documents and official speeches of Morales or Choquehuanca related to vivir bien (See Ministerio de Relaciones Exteriores, 2010). On the concept of vivir bien, see Waldmüller (2014), Beling and Vanhulst (2014), and the volume edited by Farah H. and Vasapollo (2011).

${ }^{14}$ Álvaro García Linera famously claimed that their government was opening the era of the emergence of the "Andean-Amazonian capitalism".
} 
analysts to characterise Morales' policies as developmentalism with a varnish of vivir bien: "There is no government in dispute between developmentalism and 'vivir bien', but an administration that has already defined its path: state capitalism, even though it keeps the eco-indigenist discourse — with some strength in foreign affairs - as coverage and a source of legitimacy and construction of anti-capitalist mystique" (Stefanoni, 2010, p. 171).

A second criticism of the paradigm of vivir bien comes from a recent scholarship trend that criticises an over-simplification in the clear-cut division between the interests of indigenous movements and the consequences of extractive industries. Mapping the different interests showed by indigenous and non-indigenous groups in the Tipnis confrontation, McNeish (2013) defended a more nuanced view of the process that brought to the fore the protagonism of indigenous groups in defending and promoting their territory, instead of only resisting the government's extractivism and environmental threats. Fabricant (2013) exposed the limitations of the vivir bien approach in dealing with the environmental problems of urban Bolivia, such as the water shortage and contamination in El Alto.

The analysis carried out here, on development expectations among alteños during October 2003, could perfectly match these diagnostics of the distance between vivir bien and the reality of Bolivian society. However, the identification that the development petition was accompanied by a claim for balance and equality, deeply rooted in the Bolivian society, can shed new light on this debate.

According to Xavier Albó (2011, p. 135), one of the characteristics of the concept of suma qamaña, good living in Aymara, is that it rejects the idea of "better". In other words, it rejects a relative position of superiority, not only in time (our situation is better than before) but mainly regarding others (our situation is better than others). He argues that the idea of suma already includes in itself the "greatest possible degree". The Aymaras are "resistant to saying 'better", he explains, "because it is most times understood as a group or individual that lives and is better than the others, at their expense". This seems to be Evo Morales' perception of the concept:

Vivir bien is not the same as vivir mejor [living better], living better than the other. Because for the vivir mejor, with regards to the other, it is necessary to exploit. There is competition, some want to live better while others, the majority, live badly. There is a big difference, since vivir bien is to live under equal conditions and and vivir mejor is selfishness, a lack of commitment with other people, individualism (Morales, 2010, p.9). 
While Morales' perspective on the concept reflects a more universal, anti-capitalist and left-wing perspective, there are other authors besides Albó that locate in Andean thought this denial of imbalance and group superiority, even in a situation of conflict and war. Tristan Platt's analysis of the Aymara concepts of ch'axwa, a war between two irreducible sides, and muxsa, their process of reconciliation after, is also useful to contextualise the Andean perspective on balance and fairness. According to him, there is a flow between ch'axwa and muxsa, in which the authority established after the end of a warfare period is progressively reshaped towards a balance of powers. Platt analyses the development of Aymara political thought and proposes that there is a continuous process of negotiation of the limits of authority, in which the fighting sides must re-socialise themselves through a more equal share of power (Platt, 1987, p. 97-98). This mentality informed the relationship the Aymara people established with the Incas, the colonial and the republican Bolivian state, in which territorial autonomy was granted in exchange for taxes and the recognition of state authority. Rebellions only flourished in the Andean region, argues Platt, during historical periods when this pact was broken (Platt, 1987, p. 121).

It can be noted, thus, that this perception of balance is deeply rooted both in the tradition of Aymara thought and in a more egalitarian and socialist tradition. While vivir bien can be considered a popular and easily translated concept amongst Bolivian social movements when one uses the counter-concept of vivir mejor, this idea refers only to other people. It does not necessarily deny a perspective of progress and development but does counteract the idea of group superiority.

\section{Final remarks}

Over the last decades, a number of scholars have criticised the prevalence of models development based on economic growth and extractivism in the world. Acosta (2016) identifies a "dead end" in which "the limits of Nature, rapidly overflowed by anthropocentric life-styles, particularly exacerbated by the demands of capital accumulation, are increasingly noticeable and unsustainable". Besides, the concept of development itself has been criticised as being a colonial tool of Western thought, a "set of discursive power relations that construct a representation of the Third World" (Escobar, 1992, p. 47), "robbing peoples of different cultures of the opportunity to define the forms of their social life" (Esteva, 2010, p. 5).

In this regard, the idea of vivir bien represents a welcome alternative model, since it is rooted in Latin American indigenous 
thought, ${ }^{15}$ proposes a more equitable relationship between humankind and nature, and has the potential to foster "responses to the devastating effects of climate change" and to the unsustainable expansion of capital and consumerism" (Acosta, 2016). However, as the case of El Alto demonstrates, such a promising paradigm is hard to find in the imaginary of rank-and-file activists, many of whom are of indigenous origins, speak Aymara and consider themselves to be against capitalism and neoliberalism, and still prefer to defend more standard development strategies. Even though vivir bien enthusiasts underline that the concept is still a work in progress, it is problematic that an idea supposed to be devoid of neo-colonial impositions and expressing a more authentic local thought is actually not prevalent among the mobilized popular sectors of the societies that articulated the paradigm in the first place. This is the main problem that guided the reflections carried out in this article.

In order to cast new light on this apparent unsolvable contradiction, which resembles the old Marxist problem of assigning a "false consciousness" to the working class, a first important step is to break the dichotomy between Western and Non-Western ideas and their respective negative and positive characteristics. Bolivian society, as many others in Latin America, is a result of unequal and sometimes quite violent encounters, which were nonetheless constitutive of what this society is today. It is impossible to understand indigenous rural communities in contemporary highland Bolivia without considering the deep impact of Catholicism and sixteenth-century Toledan territorial reforms. By the same token, Bolivian perspectives on development have been constructed mixing international paradigms with national collective memories, such as the War of the Pacific. When alteños proposed the October agenda defending the nationalisation of gas, articulating the known tropes of "stolen development" and "outstanding debts" represented by the maritime demand, they were defining their ideal forms of social life. Scholars and environmentalists may disagree with alteños, identifying that they did not pay enough attention to the limits of industrialisation, growth and extractivism, but the October agenda was nonetheless an authentic product of one of the most creative and transformative social rebellions in recent Latin American history.

When we recognise this process, our understanding of vivir bien changes: it becomes not only an idea under construction but also an idea to be championed. This takes us to a second important step to disentangle the

\footnotetext{
${ }^{15}$ See Yampara's (2017) interpretation of the Aymara concept suma qamaña as related to the life in the ayllus, indigenous geographical, ethnic and political units in the rural Andes.
} 
contradiction stated above: we have to look at the possible ways this paradigm can be articulated with respect to other popular and rooted political ideas in Bolivia. This research investigates one of them: the deep notion of power balance and redistribution that rejects a position of superiority achieved at the expense of others. It might seem tautological to talk about a home-made suma qamaña in Bolivia, but this is precisely the conclusion of this paper. Political ideas such as the necessary transition from ch'axwa to muxsa, the promises of a socialist society, and the recovery of the seacoast are some of the many elements that feed the fertile soil in which vivir bien can grow and, in this way, will be able to become a real potential solution for the dead ends humankind faces today.

\section{References}

ACOSTA, A. Post-growth and post-extractivism: two sides of the same cultural transformation. Alternautas, v. 3, n. 1, 2016<http://www.alternautas.net/blog/2016/4/6/ post-growth-and-post-extractivism-two-sides-of-the-same-cultural-transformation? rq=acosta $>$ (21 July 2017).

ALBÓ, X. Suma qamaña = convivir bien. ¿Cómo medirlo? In: I. Farah H.; L. Vasapollo (Eds). Vivir bien: ¿Paradigma no capitalista? La Paz: Cides-Umsa; Sapienza Università di Roma; Oxfam, 2011. p. 133-144.

BELING, A. E.; VANHULST, J. Buen vivir: new wine in old wineskins? Alternautas, v. 1, p. 29-40, 2014.

BENFORD, R. D.; SNOW, D. A. Framing processes and social movements: an overview and assessment. Annual Review of Sociology, v. 26, p.611-639, 2000 $<10.1146$ /annurev.soc.26.1.611>.

BOLIVIA - MINISTERIO de Relaciones Exteriores. Vivir bien. Mensajes y documentos sobre el Vivir Bien 1995-2010. La Paz, 2010.

CARBALLO, A. E. The opportunity of Latin American critical development thinking. Alternautas, v. 1, p. 6-16, 2014.

CUNHA FILHO, C. M. A construção do horizonte plurinacional: liberalismo, indianismo e nacional popular na formação do Estado boliviano. Tese de doutorado em Ciência Política do Instituto de Estudos Sociais e Políticos da Universidade do Estado do Rio de Janeiro, 2015.

DEMELAS, D. Nationalisme sans nation? La Bolivie aux XIXe-XXe siècles. Paris: CNRS, 1980.

EASTERLY, W. The ideology of development. Foreign Policy, 30 Oct. 2009. < http:// foreignpolicy.com/2009/10/13/the-ideology-of-development/> (31 March 2017).

ESCOBAR, A. Imagining a post-development era? Critical thought, development and social movements. Social Text, v. 31/32, n. 31, p. 20-56, $1992<10.2307 / 466217>$.

ESTEVA, G. Developement. In: W. Sachs (Ed.). The development dictionary: a guide to knowledge as power. 2. ed. London: Zed Books, 2010. p. 1-34. 
FABRICANT, N. Good Living for whom? Bolivia's climate justice movement and the limitations of indigenous cosmovisions. Latin American and Caribbean Ethnic Studies, v. 8, n. 2, p. 159-178, $2013<10.1080 / 17442222.2013 .805618>$.

FARAH H., I.; VASAPOLLO, L. Vivir bien: ¿Paradigma no capitalista? La Paz: Cides-Umsa; Sapienza Università di Roma; Oxfam, 2011.

FREITAS, C. C. de M. Entre wiphalas, polleras e ponchos: embates entre os discursos de Conamaq, do Estado Plurinacional da Bolívia e do direito internacional. Tese de doutorado em Antropologia, Universidade de São Paulo, 2013.

GAMBOA ROCABADO, F. La Asamblea Constituyente en Bolivia: nna evaluación de su dinámica. Fronesis, v. 16, n. 3, p. 487-512, 2009.

GAMSON, W. A. Talking politics. Cambridge: Cambridge University Press, 1992.

GARCÉS, F. The domestication of indigenous autonomies in Bolivia: from the Pact of Unity to the New Constitution. In: N. Fabricant; B. Gustafson (Ed.). Remapping Bolivia: resources, territory, and indigeneity in a plurinational state. Santa Fe: SAR Press, 2011. p. 46-67.

GARCÍA LINERA, Á. Empate catastrófico y punto de bifurcación. Crítica y Emancipación: Revista Latinoamericana de Ciencias Sociales, v. 1, n. 1, p.23-33, 2008 .

GOMEZ, L. A. El Alto de pie: una insurrección aymara en Bolivia. La Paz: HdP; Comuna; Indymidia, 2004.

GUTIÉRREZ AGUILAR, R. Los ritmos del Pachakuti. La Paz: Textos rebeldes, 2008.

HALBWACHS, M. On collective memory. Chicago: The University of Chicago Press, 1992.

HUYSSEN, A. Present pasts: urban palimpsests and the politics of memory. Stanford: Stanford University Press, 2003.

HYLTON, F.; THOMSON, S. The Chequered rainbow. New Left Review, v. 35, p. 41-64, 2005.

HYLTON, F.; THOMSON, S. Revolutionary horizons: past and present in Bolivian politics. London: Verso, 2007.

IAMAMOTO, S. A. S. El nacionalismo boliviano en tiempos de plurinacionalidad. La Paz: Servicio Intercultural de Fortalecimiento Democrático, Tribunal Supremo Electoral, 2013.

IAMAMOTO, S. A. S. Traditional development or vivir bien? An analysis of the Bolivian 'Gas War' in 2003. Alternautas, v. 2, n. 1, p. 32-44, 2015.

IAMAMOTO, S. A. S. Visões de nação na constituinte boliviana. Lua Nova, v. 97, p. $13-51,2016<10.1590 / 0102-6445013-051 / 97>$.

LEONEL JUNIOR, G. O Novo constitucionalismo latino-americano: um estudo sobre a Bolívia. Lumen Juris, 2015.

LUYKX, A. The Citizen factory: schooling and cultural production in Bolivia. Albany: State University of New York Press, 1999. 
MCNEISH, J.-A. Extraction, protest and indigeneity in Bolivia: The Tipnis Effect. Latin American and Caribbean Ethnic Studies, v. 8, n. 2, p.221-242, 2013 $<10.1080 / 17442222.2013 .808495>$.

MORAES, R. A. DE. Desenvolvimento e Vivir Bien: o caso do território indígena e Parque Nacional Isiboro Sécure. Dissertação (Mestrado em Estudos Comparados sobre as Américas) - Universidade de Brasília (UnB), 2014.

MORALES, E. Discurso de investidura. Discursos para la historia, $2006<$ https:// discursosparalahistoria.wordpress.com/2010/03/16/evo-morales-discurso-deinvestidura/> (31 March 2017).

MORALES, E. Vivir Bien no es lo mismo que vivir mejor. In: Ministerio de Relaciones Exteriores de Bolivia (Ed.). Vivir bien. Mensajes y documentos sobre el Vivir Bien 1995-2010. La Paz: 2010. p.9-10.

NAIRN, T. The break-up of Britain: crisis and neo-nationalism. 3. ed. Altona Vic: Common Ground, 2003.

ORTEGA, J. Aspectos del nacionalismo boliviano. Madrid: José Porrúa Turanzas, 1973.

PANNAIN, R. N. A crise do estado boliviano e a autonomia indígena. Tese (Doutorado em Sociologia) - Universidade de São Paulo (Usp), 2014.

PERREAULT, T. From the Guerra del Agua to the Guerra del Gas: resource governance, neoliberalism and popular protest in Bolivia. Antipode, v. 38, n. 1, p. 150-172, 2006 $<10.1111 / \mathrm{j} .0066-4812.2006 .00569 . x>$.

PERRIER BRUSLÉ, L. La Bolivie, sa mer perdue et la construction nationale. Annales de géographie, v. 689, p. 47-72, $2013<10.3917$ /ag.689.0047>.

PLATT, T. Entre Ch'axwa y Muxsa. Para una historia del pensamiento político Aymara. In: T. Bouysse-Cassagne et al. (Ed.). Tres reflexiones sobre el pensamiento andino. La Paz: Hisbol, 1987. p. 61-132.

POSTERO, N. Morales's MAS Government: Building indigenous popular hegemony in Bolivia. Latin American Perspectives, v. 37, n. 3, p. 18-34, 2010 $<10.1177 / 0094582 X 10364031>$.

PRESIDENCY of the Republic Bolivia. The Blue Book: the maritime claim of Bolivia. La Paz: Presidency of the Republic; Ministry of Foreign Affairs, 2004.

RADIO PACHAMAMA. Para que el tiempo no borre la memoria... no a la impunidad (audio CD). El Alto: Centro de Promoción de la Mujer Gregoria Apaza, 2004.

ROTHBERG, M. Multidirectional memory: remembering the Holocaust in the age of decolonization. Stanford: Stanford University Press, 2009.

SCHAVELZON, S. El nacimiento del estado plurinacional de Bolivia: etnografía de una asamblea constituyente. La Paz: Plural; Cejis, 2012.

SELBIN, E. Stories of revolution in the periphery. In: J. Foran; D. Lane; A. Zivkovic (Ed.). Revolution in the making of the modern world: social identities, globalization and modernity. New York: Routledge, 2008. p. 130-147.

STEFANONI, P. 'Qué hacer con los indios...' Y otros traumas irresueltos de la colonialidad. La Paz: Plural, 2010. 
SVAMPA, M. Termina la era de las promesas andinas. Clarín, 25 Aug. 2015.

SVAMPA, M.; VIALE, E. Maldesarrollo: la Argentina del extractivismo y el despojo. Buenos Aires: Katz, 2014.

WALDMÜLLER, J. M. Buen Vivir, Sumak Kawsay, 'Good Living': an introduction and overview. Alternautas, v. 1, p. 17-28, 2014.

WEBBER, J. R. Red October: left-indigenous struggles in modern Bolivia. Leiden: Brill, 2011a <10.1163/ej.9789004201552.i-376>.

WEBBER, J. R. From rebellion to reform in Bolivia: class struggle, indigenous liberation, and the politics of Evo Morales. Chicago: Heymarket Books, 2011b.

YAMPARA HUARACHI, S. The ayllu and territoriality in the Andes. Alternautas, $2017<$ http://www.alternautas.net/blog/2017/5/22/the-ayllu-and-territoriality-in-theandes> (21 July 2017).

Received on: 31 March 2017

Approved on: 11 July 2017

Correspondent author:

Sue A. S. Iamamoto

Rua Prof. Sabino Silva, 299, ap. 102 - Jd. Apipema

40155-250 Salvador, BA, Brazil 